\title{
Women Writers and the Dutch Stage: Public Femininity in the Plays of Verwers and Questiers
}

\author{
Martine van Elk
}

In the seventeenth century the plays performed at the Amsterdam Schouwburg, the only public theater in the city, were overwhelmingly written by men. Dutch theater shared with English theater a long-standing prohibition on female acting in institutionalized theatrical spaces, which was not lifted until 1655, when the first actress played a leading role in the Schouwburg. By then two women playwrights, Catharina Verwers and Catharina Questiers, had seen their plays produced for the stage. Verwers's only play was performed in 1644, over ten years before Ariana Nozeman made her debut, while Questiers's plays were written and performed between 1655 and 1665 . Given the vexed position of women in the public sphere and in particular their complex relationship to the public theater, this essay explores these playwrights' representations of women in public and private. Both Verwers and Questiers present women in public as lacking in power; they must submit to conventional versions of public femininity and empty themselves of private desires and motivations in order to occupy a public space. An effective public femininity that is coherent, strong, and independently articulated is not yet possible without sacrifice in these plays. Still, by presenting a range of female public presences and conflicted attitudes towards them, Verwers and Questiers allowed their audiences to reflect on and consider the nature of the public sphere itself and its relationship to gender.

Before we turn to the plays, some historical context for the relationship of Dutch women to the public-private divide is necessary. As extensive study has shown, those terms were unstable and in flux in the seventeenth century. Traditional understandings of the public and private realms were influenced by absolutist political systems, which presented the two as mutually constitutive and parallel spheres of being, as the familiar tendency to treat the home as the microcosm of the commonwealth suggests. ${ }^{1}$ Yet, Jürgen Habermas has argued,

1 The parallel, seen in the type of political thinking identified as patriarchalism, is important to writings about the family and the state all over Europe. For the English context, see Michael McKeon's The Secret History of Domesticity: Public, Private, and the Division of Knowledge 
as a consequence of the Reformation and the questioning of absolutism, a new understanding of public and private emerged. Not only did the domestic sphere come to be seen as a space for devotion and spiritual reform, making it fundamentally different from the public realm, but the public sphere itself would eventually emerge as a site for rational exchange by citizens on the basis of reason, rather than deference to authority. ${ }^{2}$ This double development - the rise of an ideology of domesticity and of a newly conceived public sphere - was particularly important to women, who had always been positioned as properly in the household but whose domestic presence now came to be seen as vital to social order, national identity, and religious reformation. Such ideological and conceptual shifts do not necessarily match social practice, of course. Women were still active in the marketplace as buyers and sellers, but the change in thinking all over Europe had a strong impact on notions of ideal and especially elite femininity. ${ }^{3}$ These changes suggest the potential for female "agency" in the sense in which Martha Howell uses the term, as "born in the contradictions that are inherent in discursive structures." ${ }^{n}$ Those contradictions are in this case a product of uneven developments over time in conceptions of the public-private divide.

The lateness of the arrival of the Dutch actress on the public stage and the near-simultaneous emergence of a small number of female playwrights should be placed in this cultural context. The stage in general had long been considered an inappropriate venue for women, given the association of female acting with prostitution and the general obstacles to female public action and speech, current all over early modern Europe and rooted in biblical injunctions and legal prohibitions. In spite of all this, the tradition of all-male acting and

(Baltimore: The Johns Hopkins University Press, 2005). This way of thinking is also frequently found in the works of Dutch humanists and reformers. McKeon's work is central to my analysis of the public-private relationship in this period.

2 Though his theory has been criticized for not paying enough attention to the public sphere as an exclusionary realm and for not acknowledging other forms of public spheres and counterpublics, Habermas's work continues to be fundamental to much historicizing of and theorizing about the public sphere. Jürgen Habermas, The Structural Transformation of the Public Sphere: An Inquiry into a Category of Bourgeois Society, trans. Thomas Burger (Cambridge: The Mit Press, 1991).

3 Wider contexts for representations of female publicity in English and Dutch texts of this period are described in my book, Early Modern Women's Writing: Domesticity, Privacy, and the Public Sphere in England and the Dutch Republic (Cham: Springer/Palgrave Macmillan, 2017). For historical information on women in the marketplace, see among others, Danielle van den Heuvel, Women and Entrepreneurship: Female Traders in the Northern Netherlands, c. 1580-1815 (Amsterdam: Askant, 2007).

4 See Howell's essay in this volume, chapter 1, 31 . 
transvestite performances by men and boys was gradually abandoned, partly under the influence of traveling players and fairground performances by women. ${ }^{5}$ Although it is difficult to pinpoint a definitive explanation for the delay in female acting in the Dutch Republic, when it comes to playwriting, a possible reason for the relative scarcity of women playwrights in the period is the collaborative and intensely public nature of the stage. The works of Dutch women writers were often treated as properly part of elite, elegant pastime and smallscale social exchange, suitable for a limited audience of friends and family. Typically, though not always, women were supposed to stop writing or circulating their works widely upon marriage, purportedly because a married woman would no longer have time for such activities. Naturally, plays for the public stage do not fit the domestic categorization of pastime. The cultural environment of the Schouwburg created further impediments to female playwriting. The only public theater in Amsterdam, founded in 1638, the Schouwburg had its roots in the male-dominated tradition of the Rederijkerskamers (Chambers of Rhetoric). It was both a charitable and profit-oriented institution: the board of regents was appointed by the city council, proceeds went to charity, and the stated aim of its founders was to educate the general public and shape Dutch identity in the young Republic, an enterprise in which women functioned as muses rather than active participants. ${ }^{6}$

Still, by the later seventeenth century, when women on stage had become a familiar sight, Jacob Lescailje's print shop, which was licensed to do all print work for the Schouwburg, was run by his daughters, and three Dutch women, including Lescailje's eldest daughter Katherine, saw their plays produced for public performance. All three wrote drama based on Spanish and French plays, including works by Lope de Vega and Pierre Corneille. That these women wrote adaptations and translations is not remarkable or necessarily tied to their gender. The extraordinary popularity of Spanish drama on the Dutch stage could be considered surprising in light of the political hostility between the two countries. Yet, as theater historians have shown, when playwrights chose Spanish source texts, whether they read them in the original, in French, or in a commissioned translation into Dutch, political considerations seem to have been largely ignored. Spanish plays were very fashionable and above all

5 For an overview of the tradition of female impersonation by men, see Louis Peter Grijp, "Boys and Female Impersonators in the Amsterdam Theatre of the Seventeenth Century," Medieval English Theatre 28 (2006): 131-70. See for the earliest actresses, my essay, "Before she ends up in a brothel': Public Femininity and the First Actresses in England and the Low Countries," Early Modern Low Countries 1.1 (2017): 30-5o, http://doi.org/10.18352/emlc.5.

6 For an overview of the theater in Amsterdam, see Mieke B. Smits-Veldt, Het Nederlandse Renaissancetoneel (Utrecht: Hes, 1991). 
profitable, helping the Schouwburg acquire the repertoire it needed to cater to its audience. ${ }^{7}$ Even though humanists considered translation a more appropriate type of writing for women than original composition, on the Dutch stage it was not a gendered phenomenon of an oppressive nature, nor did it indicate inexperience or lack of education. ${ }^{8}$ Like their male counterparts, these women, I hope to show, found ways to incorporate their own ideas into these plays, particularly when it came to public femininity and female sexuality. In that respect, they resembled other women writers whose translations represented "a highly coded political or ideological intervention," as Danielle Clarke puts it. ${ }^{9}$ Clarke is mainly concerned with translation as an activity in the domestic sphere, but the public stage, with its collaborative mode of production, was capable of disseminating a translator's voice more widely than other types

7 Female playwrights were closely following dramatic trends. Karel Porteman and Mieke B. Smits-Veldt estimate that at least two-thirds of new plays staged between $165^{1}$ and 1672 were translations and adaptations from Spanish and French, with Spanish plays dominating until about 1665 and French plays afterwards. Een nieuw vaderland voor de muzen. Geschiedenis van de Nederlandse literatuur, 1560-170o, vol. II of Geschiedenis van de Nederlandse literatuur, ed. A. J. Gelderblom and A. M. Musschoot (Amsterdam: Bakker, 2008), 525. Research into numbers, reception, and case studies of playwrights has been done by Kim Jautze, Leonor Álavarez Francès, and Frans R. E. Blom, "Spaans theater in de Amsterdamse Schouwburg (1638-1672). Kwantitatieve en kwalitatieve analyse van de creatieve industrie van het vertalen," De Zeventiende Eeuw 32 (2016) I, 12-39. See also other essays in the same volume and especially the helpful introductory essay, "Neem liever een Spaans spel.' Nieuw onderzoek naar Spaans toneel op de Noord- en Zuid-Nederlandse planken in de zeventiende eeuw," by Yolanda Rodríguez Pérez, 2-11. For French drama, see Anna de Haas, "Frans classicisme en het Nederlandse toneel, 1660-1730," De Achttiende Eeuw 29 (1997): 127-40, and, especially for female translations, see Pim van Oostrum, "Dutch Interest in 17th- and 18thCentury French Tragedies Written by Women," in 'I have heard about you.' Foreign Women's Writing Crossing the Dutch Border: From Sappho to Selma Lagerlöf, ed. Suzan van Dijk et al., trans. Jo Nesbitt (Hilversum: Verloren, 2004), 153-72.

8 Annelies de Jeu is aware of the dominance of translated plays but calls translation "good practice material" for women playwrights "considering their inexperience with the genre." 't Spoor der dichteressen. Netwerken en publicatiemogelijkheden van schrijvende vrouwen in de Republiek (1600-1750) (Hilversum: Verloren, 2000), 214.

9 Although she deals with England, Danielle Clarke's discussion of the ways in which translation could enable expression is relevant to the Low Countries and these plays in particular. "Translation," in The Cambridge Companion to Early Modern Women's Writing, ed. Laura Lunger Knoppers (Cambridge: Cambridge University Press, 2009), 167-80, esp. 169. For female political interventions through translation, see for instance, Mihoko Suzuki, "Women, Civil War, and Empire: The Politics of Translation in Katherine Philips's Pompey and Horace," The History of British Women's Writing, 1610-169o, vol. 3, ed. Mihoko Suzuki (Houndmills: Palgrave, 2011), 270-86, and for a Dutch non-dramatic example, my "Courtliness, Piety, and Politics: Emblem Books by Georgette de Montenay, Anna Roemers Visscher, and Esther Inglis," Early Modern Women and Transnational Communities of Letters, ed. Julie D. Campbell and Anne R. Larsen (Burlington: Ashgate, 2009), 183-212. 
of translation. The two plays I discuss in this essay do not suppress the culturally dominant associations between public femininity and eroticism. They show clearly that their authors saw public femininity as a product of available cultural discourses. Thus, to return to Howell's argument, what we might perceive as "agency" in these plays is located less in overt challenges to patriarchy or negotiation of its restrictions than in reflection on its workings and contradictions. Verwers and Lescailje reveal that public femininity is an outcome of the interplay of male views of female sexuality and virtue on the one hand and women's ability to control their own public presence on the other. Both are specifically concerned with elite femininity and courtliness: Verwers offers a Reformed revision of elite ideals but also presents us with an allegory of female fame, while Questiers contemplates the repression of the personal that is required of public women. In both plays, the marriage at the end promises to transform the relationship between female public and private life. Although the marriage itself brings fame in Verwers's play, there is no indication that her protagonist will any longer perform in public; in Questiers's text, marriage can convey or retain political authority for women, but only if the private self is suppressed.

\section{Verwers: Romance Reformed}

The first play by a Dutch woman performed on the public stage of the Schouwburg was Spaensche heydin (Spanish Pagan, 1644), based on the novella La gitanilla (The Little Gypsy Girl, 1613) by Miguel de Cervantes. Catharina Verwers (c. 1618-1684) is a somewhat enigmatic figure because, unlike the other female playwrights mentioned in this essay, she had no known familial connections to the theater..$^{10}$ Moreover, although she may have composed the play while unmarried, she had been married for close to two years in 1644, when it was staged and printed - this at a time when most Dutch women writers were expected to stop publishing once they became wives and mothers." There is much we

10 De Jeu notes that there is a Dirck Claeszoon Verwer among the regents of the Schouwburg in the records for 1646-49. 't Spoor der dichteressen, 215. However, as yet we have no evidence that they were indeed related, and Verwers's play was in any case first staged before he was a regent (1645-49). C. N. Wybrands, Het Amsterdamsche tooneel van 1617-1772 (Utrecht: Beijers, 1873), 227-28.

11 Verwers did not publish much after her play, aside from a few poems and a contribution to a poem by multiple authors, printed in 1654 . She lived in fairly affluent artistic households: her father was a successful painter of seascapes, and her husband, Christian Dusart, was a painter who probably studied under Rembrandt. Born into an Anabaptist 
do not know about the play. We do not know its precise date of composition, and there is a lack of clarity about how often it was performed and what its relationship is to another contemporary play based on the same story with the same title. The other play, also entitled De Spaensche heidin (The Spanish Pagan), written by Mattheus Gansneb Tengnagel, was published together with Tengnagel's prose retelling of the story in 1643. We do know that Verwers's play was composed before Tengnagel's and that it was circulating for at least 11 months before its first recorded performance at the Schouwburg in June $1644 \cdot{ }^{12}$ The revival of Verwers's play in the late 165 os suggests continued interest in the story, giving audiences the opportunity to see the play performed for the first time with an actress in the lead. ${ }^{13}$ In terms of revenue, Verwers's play seems to have been on average somewhat more successful than Tengnagel's in their initial runs and, if the revival was indeed of her play, more successful overall. ${ }^{14}$

family, she converted, once married, to the Remonstrant Church. She was friends with Questiers, but Questiers's first play postdates Verwers's by eleven years, so that cannot be seen as a clear theatrical connection. For her biography, see Els Kloek, "Verwers, Catharina (ca. 1618-1684)," Digitaal vrouwenlexicon van Nederland, Huygens Instituut voor de Nederlandse Geschiedenis, web, 2014. For a discussion of the issue of marriage and examples of married women writers, see a blog post by Nina Geerdink, "The Phenomenon of the Married Woman Writer in the Dutch Republic," Early Modern Women: Lives, Texts, Objects, web, November 2017.

12 In Tengnagel's dedicatory letter dated 14 July 1643 , he apologizes to those who see too much of their own work in his book, including Verwers, who, he says, "tried to turn [the story] into a play and show it on stage" ("[De geschiedenis] tot een spel te brengen, en op het tooneel te vertoonen, gepoogt heeft"). M[attheus] G[ansneb] T[engnagel], Het leven van Konstance, Waer af volgt het tooneelspel, De Spaensche heidin (Amsterdam, 1643), 167 ; $\mathrm{X} 4 \mathrm{r}$.

13 The ONSTAGE database assigns all five performances in the 1650 s to Tengnagel. However, based on the listing of roles for the $165^{8}$ performance in the Parsonagieboek (Bookof Roles), it is clear that the last of these five performances is definitely of Verwers's play. It seems most likely that all five were of her play, not Tengnagel's. ONSTAGE: Online Datasystem of Theatre in Amsterdam in the Golden Age, Amsterdam Centre for the Study of the Golden Age, University of Amsterdam. For the listing in the Parsonagieboek, see C. N. Wybrands, "De Amsterdamsche schouwburg gedurende het seizoen 1658-1659," Het Nederlandsch tooneel 2 (1873) 246-322, esp. 267. Wybrands mistakenly lists the play as Tengnagel's, an attribution that does not appear in the original record, available on-line in the stadsarchief Amsterdam, Archief van het Burgerweeshuis 367A, Exploitatie van de Schouwburg 1.2.3.2., nr. 429, fol. 19. See also E. Oey-de Vita and M. Geestink, Academie en schouwburg. Amsterdams toneelrepertoire, 1617-1665 (Amsterdam: Huis aan de drie grachten, 1983), 193. I have explained this discrepancy in more detail in a blog post, "Catharina Verwers: A Mysterious First Playwright," Early Modern Women: Lives, Texts, Objects, web, June 2016.

14 De Jeu believes that Verwers's initial run was less successful because Tengnagel produced his play first, but Verwers's play premiered in June and Tengnagel's in September, and the numbers do not bear this out. If we look at the average revenue for each play in ONSTAGE, 
Spaensche heydin is not a translation of any identifiable Spanish play. It was unusual at this time for Dutch male and female playwrights to be conversant in Spanish, but it is possible that Verwers read the story in French or commissioned a prose translation. She may even have revised her work after reading Tengnagel's play. ${ }^{15}$ However, she certainly and probably primarily used a poetic adaptation of the story by Jacob Cats, who included it in his highly popular 1637 Trou-ringh (Wedding Ring). ${ }^{16}$ Clearly, Verwers engaged in a complex, creative, and intertextual form of writing, possibly using multiple sources in composing the play but following none of them closely. She ultimately revises the female figures in two directions: on the one hand, she reduces their courtliness and presents them in enclosed or pastoral rather than public spaces, but on the other, she also presents the fame of the protagonist in allegorical terms. These contradictory representations show the extent to which the instability of the public-private divide affected public femininity on stage.

In brief, Cervantes's story is a romance narrative, complete with conventional emphases on high social status, temporary loss of identity, and ultimate marriage between social equals. As is true of beggars in the period, the figure of the "gitanilla" was a romanticized, literary construction that bore little relation to real itinerant Romanis in the period, who were persecuted throughout Europe. Dutch authors tended to use the term "heiden" or "pagan" for such traveling communities; the word "zigeuner," while seen occasionally as early

it appears that Verwers's play took in a bit more revenue than Tengnagel's on average in the 1640 s (about 167 guilders versus about 162 guilders), but neither play was especially popular. The performances in the 1650 s, presumably of her play, took in an average of about 216 guilders per performance. Cf. Annelies de Jeu, "'Hoe dat een Vrouwen-beelt kan maken zulke Vaarzen': Reacties op de toneelstukken van Catharina Verwers en Catharina Questiers," in Kort tijt-verdrijf. Opstellen over Nederlands toneel (vanaf ca. 1550). Aangeboden aan Mieke B. Smits-Veldt, ed. W. Abrahamse, A. C. G. Fleurkens, and M. Meijer Drees (Amsterdam: A D \& L, 1996), 179-84, 180-81.

15 Kloek, "Verwers, Catharina." Dennis Koopman has published on-line two chapters on the Dutch reception and use of La Gitanilla and argues that there is no evidence Verwers used Cervantes at all. Cervantes, Cats en de Amsterdamse Schouwburg. De geschiedenis van een Spaans zigeunermeisje, web, 2008.

16 This is the conclusion of the second of two chapters by Koopman, Cervantes. Cervantes's novella was translated into Dutch in 1643 by Felix van Sambix, although his translation probably postdates the composition of Verwers's play. Cats's version appeared originally in 's Werelts begin, midden, eynde, besloten in den Trou-ringh, met den Proef-steen van den zelven (The World's Beginning, Middle, End, Contained in the Wedding Ring, with the Touchstone of the Same; Dordrecht: Kannewet, 1637), vol. 3, Nnn4r-Ttt4v; 471-520. The full title is "Selfsaem Trou-geval tusschen een Spaens edelman, ende een heydinne; Soo als de selve edelman, ende alle de werelt doen geloofde" ("Rare case of marriage between a Spanish nobleman, and a pagan; Such as the same nobleman, and the entire world then believed"). 
as the sixteenth century, was not common usage until after the early modern period. ${ }^{17}$ Cervantes's story centers on Preciosa, a young woman who, it turns out, is in fact noble: she was kidnapped as a young child by an older itinerant woman, called Majombe in Cats's version, who pretends to be her grandmother. A nobleman named Don Juan falls in love with her and is told he may marry her on condition that he join the travelers for a certain period of time. A rich lady falls in love with Don Juan in his "gypsy" disguise and, when he rejects her advances, plots to have him falsely accused of theft in front of a local magistrate. When insulted by a soldier about the theft, Don Juan kills the man in a fit of anger, only to end up facing a murder as well as a theft charge. In the climactic final part of the story, Preciosa pleads for Don Juan's life to the local magistrate, who turns out to be her own father. All is revealed, everyone is forgiven, and in quick succession, Preciosa is reunited with her parents and married to Don Juan.

The relationship between public and private is configured in this story primarily through the category of the visible, with increased visibility for the female protagonist as an indicator of a powerful public presence. ${ }^{18}$ In a traditional absolutist society, respectable public femininity was elite femininity, marked by the display of noble virtue as well as elegance and sophistication, making visible performance key; other forms of female visibility were associated with prostitution and the marketplace. Changing Protestant emphases on domesticity led to the formulation of a new ideal, which emphasized modesty, humility, and devoutness over high class; along with this came, predictably, a current of anti-courtliness, commonly seen in Dutch literature by Reformed writers. Exemplarity for women had been aligned with nobility and classbased virtue but would be shifted to religiosity as the crucial component of the ideal. All three Dutch versions of the story of the Spanish pagan, written by Protestants for a Dutch audience, reformulate their leading lady in the direction of the new ideal, but the result is divergent, placing these texts on the fault line between new ideologies of domesticity and older views of noble virtue.

Verwers's play most self-consciously stages the tension between these different feminine ideals, inviting the audience to reflect on representations of

\footnotetext{
17 The Geïntegreerde Taalbank (Gтв), which includes historical dictionaries of Dutch online, cites E. Buys's Nieuw en volkomen woordenboek van konsten en wetenschappen (New and Complete Dictionary of Arts and Sciences, 1769-1778), an eighteenth-century dictionary that says "zigeuners" are "Commonly called Pagans" ("Gemeenelyk Heidens genaamt").

18 See Jeff Weintraub for a useful discussion of the multiple definitions of public and private. "The Theory and Politics of the Public/Private Distinction," in Public and Private in Thought and Practice: Perspectives on a Grand Dichotomy, ed. Jeff Weintraub and Krishan Kumar (Chicago: The University of Chicago Press, 1997), 1-42.
} 
women in public and private settings. Her relationship to other versions of the story can be examined through three of its sections: the scenes prior to the meeting with Don Juan (Don Jan in the Dutch versions), the first meeting of the lovers, and the happy ending in marriage. Preciosa, spelled variously as Pretiosa (Cats), Pretioze (Tengnagel), and Pretiose (Verwers), is in each version known for her engaging dancing and singing skills, which have given her a reputation that transcends the immediate community of "gypsies." Cervantes presents her fame in the opening section of the novella as straightforwardly courtly, and it is here that we encounter Preciosa in her most comfortably public form. Her initial appearances are public spectacles: she dances and sings at occasions such as the Festival of Santa Ana, where she attracts a crowd of "more than two hundred persons." ${ }^{19}$ This is where Don Juan sees her and falls in love. In the novella, Preciosa's visibility, a traditional component of noble public femininity, does not make her seem sexually suspect, even though her "grandmother" profits from these performances. Instead, spectators remark on her nobility, grace, and courtliness; she is known to be "extremely pleasing and courteous in conversation," and in addition to her "sprightliness," there is "so much genuine decorum in her manner" that she remains within the bounds of proper morality. ${ }^{20}$ She is witty and able to speak her mind before crowds and even in the house of a stranger in front of a group of men she does not know, in a complex setting that is semi-private and therefore perhaps more dangerous than a public stage. When a fellow traveler expresses her apprehension at entering the house, Preciosa answers, "what you have to beware of is one man alone; where there are so many there is nothing to fear. Of one thing you may be sure, ... the woman who is resolved to be upright, may be so amongst an army of soldiers." ${ }^{21}$ In brief, then, she thrives before an audience, even when it is composed of men, as a typical romance heroine whose nobility shines through her supposedly marginal class status in a public manner. It is her natural courtliness that prevents sexualization of her performances.

As might be expected of Protestant authors, Cats, Tengnagel, and Verwers change their leading lady's prominence at the outset by shifting away from an emphasis on entertaining courtly performance towards a more modest, less public ideal. ${ }^{22}$ In Trou-ringh, Pretiose still arouses general admiration, yet Cats

19 I have used a modern translation. Miguel de Cervantes, "The Little Gipsy Girl," The Exemplary Novels of Cervantes, trans. Walter K. Kelly (Auckland: The Floating Press, 2014), 223-93, 226.

$20 \quad$ Ibid., 223-224.

21 Ibid, 228.

22 Verwers's parents were Anabaptists, though she converted on her marriage to the Remonstrant church (based on Arminianism). For her parents, see A. Blaauw, "Over de 
presents her as widely known for her chastening influence, not her dancing and singing. Cervantes emphasizes that his leading lady does not perform in ways that are not respectable, and she does not "permit those in her company to sing immodest songs."23 In Cats's retelling, she transforms the other "gypsies" equally thoroughly. Their respect for her is shown in the fact that "One does not hear a loose word if she is present," and he highlights her condemnation of their "dishonest activity." ${ }^{24}$ Cats's heroine is exceptional for her knowledge of palmistry, astrology, and medicine, which makes people seek her out. He sets the first meeting of the two lovers in a forest, where Don Jan loses his way during a hunt and encounters the singing young woman. ${ }^{25}$ Reflecting on her lack of courtliness, he says, "If this pagan child ... / Were to be displayed in front of us dressed in courtly fashion, / Where would her beauty go?"26 The larger work stresses the importance of compatibility over social standing in choosing a marital partner, so Cats shows Don Jan to be impressed, not by any public performance or courtly display, but by Pretiosa's goodness and "extraordinary mind." 27 When Don Juan woos her in Cervantes, Preciosa imposes the terms of their marriage, and she later reveals that although others have decided she will be married to him, the conditions are her own: "I have decreed, in accordance with the law of my own will, which is the strongest of all." 28 In Cats, by contrast, she begins by modestly rejecting him. She blushes, faults her admirer for being "full of false courtly tricks," and assures him that she knows "the nature of cunning praise." ${ }^{29}$ Combining modesty with a strong moral voice, she proudly proclaims her chastity. "Go," she tells him, "to the lustful court, and stroke the silk skirts, / Seek there adequate material for your illicit joy, / And leave me the

Waterlands doopsgezinde schilder Abraham de Verwer van Burchstraete, over zijn vrouw Barbara van Sillevoirt, en iets over zijn vroegste werken," Doopsgezinde bijdragen $3^{1}$ (2005): 75-91.

23 Cervantes, "The Little Gypsy Girl," 225.

24 The original reads, "Men hoort geen dertel woort als syder is ontrent" and she punishes "het vuyl bejagh." Cats, Trou-ringh, Ooor; 473.

25 The scene became popular in paintings at the time. See Ivan Gaskell, "Transformations of Cervantes's 'La Gitanilla' in Dutch Art," Journal of the Warburg and Courtauld Institutes 45 (1982): 263-70.

26 "Wel of dit heydens kint ... / Eens op syn hoofs gekleet voor ons ten toone stont, / Waer sou haer schoonheyt gaen?" Cats, Trou-ringh, Ppp3r; 485.

27 The original phrase is "ongemeen verstant"; ibid., Ppp3r; 485.

28 Cervantes, “The Little Gypsy Girl," 258.

29 The original phrases are "vol hooffsche treken" and "den aert van 't listigh prijsen"; Cats, Trou-ringh, Ppp3v; 486. 
noble pledge of my chaste youth."30 It is not until then that he proposes marriage; she promptly changes her mind and informs him of the two-year test he must undergo, which amounts to a demand for his rejection of the court and its customs. Thus, Cats does not deny his leading lady a public reputation, but he bases it on her morality, insight into others, and wisdom. In her private conversations, he is careful to highlight her repudiation of courtly femininity, which is presented as unchaste. The young "pagan" is the focal point of male desire, but this desire must be corrected and adjusted to confirm her chastity.

Verwers adopts several of Cats's changes, including the hunt, but also adds significant alterations of her own. As is true for Tengnagel's play, she gives Pretiose no public appearances prior to the meeting with Don Jan. In Tengnagel, the opening scene features a lengthy discussion between Pretioze and Majombe on whether or not God will protect her from harm in the forest, as they contemplate ancient examples of virgins and others beset by male lust and animal attack. The shift away from public scenes is even stronger in Verwers's version. She cuts the opening section completely, going straight to Pretiose's first meeting with Don Jan. This alters her protagonist's public presence in complex ways. Obviously, she reduces our sense of Pretiose as a performer in favor of an emphasis on her status as a love object for Don Jan. But at the same time, unlike in Tengnagel, her Pretiose is still given a theatrical entrance. Where we first become acquainted with her through her intimate conversations with Majombe in Tengnagel's play, we hear her sing "from within" in Verwers's text. Don Jan responds to the beautiful sound, upon which she enters singing and praying to Apollo to help her win an award for song and dance, which, as she explains a little later, will be given out at a festival. ${ }^{31}$ The impressive entry in Verwers emphasizes Pretiose's ability to excel at public occasions. This young woman is not engaged in palm reading or in witty discourse, but placed firmly within a classical, pagan context, reducing her exoticism and aligning her story with ancient pastoral conventions that present her in enclosed, outdoor settings but nonetheless feature performances of sorts.

In the conversation that follows, Verwers adopts the anti-court sentiment from Cats, even coming close to his language at key moments. Don Jan's first response upon seeing her, "O if one might adorn this Virgin in courtly fashion, /

$30 \quad$ She tells him, "Gaet naer het dertel hof, en streelt de sijde rocken, / Soeckt daer bequame stof voor u ongure vreught, / En laet my 't edel pant van mijn reyne jeught”; ibid., Ppppr Ppppv; 487-88.

31 The original stage direction reads, "PRECIOSE singht van binne." Katarina Verwers van Dusart, Spaensche heydin, blyspel (Amsterdam: Lescaille, 1657), A2v; 4. All quotations are taken from this second edition of the play. 
Where would her beauty go, where would it sway to?" is one of a number of striking verbal echoes. ${ }^{32}$ Verwers's heroine denounces courtly wooing in much the same terms as she uses in Cats, although her language is purged of any reference to sexuality: "go stroke the silken clothing, / And leave my chastity, to adorn my limbs; / I hate your flattery, go spend it at the Court." ${ }^{33}$ Verwers leaves out Cats's direct references to lust, and she formulates the rejection as hatred instead, making her lady morally more forceful. These moral pronouncements on courtly wooing and flattery, however, are joined with a more passive stance, as seen for instance in the fact that in this version alone, it is not Pretiose but Majombe who formulates the conditions for the marriage. Yet, Pretiose's second entry in Verwers is even more theatrical than the first: again she enters singing in praise of Apollo, now followed by a group of female "gypsies," all covered in laurel, having won the prize at the festival. Don Jan, who has decided he is willing to give up his status and wealth for her, compliments her in terms that reject courtly femininity and present her as his "Earthly goddess," but she still berates him, "You flatter me in too much of a courtly way." ${ }^{34}$ Thus, her character combines divine beauty and performance with a moralistic rejection of the court and humble modesty, at times reflected in her use of diminutives and down-to-earth turns of phrases. These revisions in the central character deemphasize her courtly fame in Cervantes's version and her reputation for wisdom in Cats's. Pretiose shines in front of large audiences in performances that Verwers refers to but does not show. Yet, she still sings, dances, and praises the pagan gods on stage, giving her character a religious presence, albeit a pagan one, that she does not have in other versions of the story.

These revisions by Verwers make Pretiose an embodiment of classical ideals, a fundamentally different approach than that found in Cats or Tengnagel. The latter turns her into a Protestant and has her sing anti-Catholic songs. Cats, whose concern is with religious compatibility, never has her worship pagan gods or explicitly convert to Christianity. Her father's lengthy speeches praising God for her return in Trou-ringh indicate that she is easily transferred from the heathen sphere of the pagans into a proper Christian marriage because of her innate virtue. By contrast, Verwers shows her leading lady singing to the pagan gods and adorned with laurels. Thus, Verwers constructs a feminine ideal that is modest, morally strong, respectable, and largely placed in fairly intimate

32 "Ach datmen dese Maeght eens op sijn Hofs ginck sieren, / Waer sou haer schoonheydt gaen, waer sou die niet heen swieren?" Ibid., A3r; 5 .

33 She tells him, "gaet streelt het sy gewaet, / En laet mijn reynigheydt, tot siersel mijner leden; / Ick haet u vleyery, gae die ten Hof besteden." Ibid., A4r; 7.

34 The original has him call her his "Aerts-godin"; she responds, "Ghy vleyt my al te Hofs." Ibid., B4r; 23. 
rural settings, but capable of performance and the subject of male praise, often in aesthetic and elevated terms. This is the cultural work of pastoral romance, which takes women out of the noble positions due to them by birth and places them within surroundings in which their nobility comes to be appreciated as natural and semi-divine, yet lacking in public impact. A Reformed sensibility is not absent, however, as we have seen in Pretiose's modesty and anti-courtliness in private conversations. To this same end, Verwers also expands the mother of Pretiose from the source texts. In her play alone, Pretiose's mother gets several domestic scenes in which she despairs and mourns the loss of her child, being comforted by her devout maidservant. Through this figure, Verwers is able to infuse the romance narrative with what we might call a broadly Protestant, middle-class, and even domestic sensibility, based in part on a critique of courtly public femininity, in particular in the form it has in Cervantes.

The ending of Verwers's play complicates public femininity further. Cats ends his poem with the line, "And the entire world rejoices because Pretiose is getting married."35 Although this is a much-reduced version of the description of the festival held at the wedding in Cervantes, Cats nonetheless highlights popular admiration for the young "pagan" and her story. In Cats and Cervantes, her public presence at the end is no longer grounded in her ability to perform, her wisdom, or her wit, but merely in her story and the events as they have unfolded. The contrast with Tengnagel's conclusion, in which several minor servant characters speak more than Pretiose, who only praises God for the happy ending, is stark, as he avoids any strong public voice for his leading lady. Verwers takes a fundamentally different approach. Her Spaensche heydin ends with general recognition of Pretiose's story as remarkable, but she gives this recognition the form of a tableau vivant or "vertoning" ("staging"). Such tableaux were frequently used in early modern Dutch drama, taking the form of a dumb show accompanied by the reading of a short verse, often for the purpose of staging key public moments such as weddings. ${ }^{36}$ The play features two of these, printed before the opening of the play but probably performed at the end when they occur in terms of plot. The first depicts the reunion between Don Jan and his father, with the latter forgiving Don Jan for his secret departure from the court and the former presenting his bride to his father. In this tableau, Pretiose is present only as private person, accepted into the family by Don Jan's father. The second tableau is a version of Cats's final line, as seen in the accompanying verse:

35 "En al de werelt juyght dat Pretiose trout"; Cats, Trou-ringh, Ttt2v; 516.

36 For more on these dumb shows in earlier drama, see E. Oey-de Vita, "Vertoningen en pantomimes in vroeg-17e-eeuwse toneelstukken (1610- \pm 1620$)$," Scenarium 8 (1984): 9-25. 
Here weds the beautiful virgin,

Of whom the entire Court speaks;

See yonder dame Fame swirl

With overloud sound,

To lead the praise of this Bride

To the world's end. ${ }^{37}$

The focus is entirely on Pretiose, who is attended by Dame Fame, a female allegory, to foreground her public role, which is now, contrary to the earlier anti-courtly sentiment of the characters, praised and validated by the entire court. She is lifted out of the immediate environment within which she functions as submissive wife-to-be and into the realm of the exceptional and supernatural. This panegyric goes beyond the happy endings in Cats and Cervantes, especially if we consider its staging possibilities. At the Schouwburg, this would have been a metatheatrical moment that breaks with the more realistic drama up to this point, to present Pretiose in way that is both glorifying and, due to the generic disruption, artificial, allowing the audience to reflect on the theater as a location for the presentation of public femininity. The artificiality would have been especially clear when the role of Pretiose was still performed by a cross-dressed male, and, though we can only speculate, might have pointed in new directions for female performance in a theatrical setting once a woman took on the role, including when, as was the case in the revival in 1658, some female roles, such as Pretiose's mother, were still played by men.

By adding this coda to her play, Verwers complicates Pretiose's public presence beyond what we see in other retellings. On the one hand, her presence in public settings has been reduced and her moral stature has an effect primarily on her husband-to-be, who becomes a figure for the respectable redirection of erotic desire for a performing woman. Tellingly, her performances are, on stage at least, only for his benefit. For most of Verwers's Spaensche heydin, the remarkable Pretiose is a less publicly visible figure than in Cervantes and Cats, even as she is visible on stage. Yet, the ending, much like the unexpected entry of Cupid in the opening scene, suddenly places the character on a different plane. Verwers gives her a fame beyond the real world and builds on her performative and ritual entrances earlier in the play. Combined with the expanded

37 "Hier trouwt de schoone maeght, / Daer 't heele Hof van waeght; / Siet gins vrouw Fama swieren / Met overhel geluydt, / Om 't lof van dese Bruydt / Aen 's werelts endt te stieren." The word "overhel" is unusual. Verwers, Spaensche heydin, *4r. 
mother figure, Verwers uses her protagonist to create a dual representation of Reformed private and allegorized public femininity. The tension between the two forms of femininity, one pointing to the new divisions in public and private favored by Reformers and the other to older, traditional visions of public and private as separate but continuous, is presented without any explicit conclusions. Thus, Verwers invites her audience to reflect on the nature of and conflict between representations of ideal femininity, which were, under the pressure of cultural developments, undergoing deep changes. Agency can be located here not in Verwers's or her characters' disruption of patriarchy or clever use of its regulations and structures, but instead in literary defamiliarization that creates awareness of contradictions between traditional and newer forms of public and private femininity.

\section{$2 \quad$ Questiers: Male and Female Pride}

If Verwers's anti-courtly play explores different types of femininity but does not imagine an active public role for women, Catharina Questiers (1631-1669) works with a different set of dramatic conventions that do allow for such a role but define the public realm differently. Her story takes place at court and involves women of royal status, unavoidably implying political importance and grave consequences for their amatory decisions and attractiveness to others. Here too, male desire is directed at a woman in a position of prominence and must reckoned with. Like Verwers, Questiers places the theme of public femininity's relation to sexuality at center stage in order to redirect that desire eventually. The courtly environment means that "public" is defined not primarily as a matter of visibility, as is true in Verwers's play, but as a matter of political influence over others and collective interest. Women at court fulfill socially and politically significant functions, whether or not they are seen to do so by larger audiences, by virtue of their marital choices and degree of willingness to align themselves with factions and individuals at court. Royal women must be visible at certain times, but their actions behind the scenes also affect the larger community. Courts are complex settings, incorporating intimate spaces and public rooms, as well as places that can be transformed in a moment from a location of conspiracy to a courtroom. In such an environment, the newer, Reformed understanding of public and private and the notion of the household as a domestic realm simply do not apply. Instead, the public is identified as what is politically significant and within the purview of the ruler and his followers; the private is associated with secrecy, conspiracy, and sexual 
betrayal. ${ }^{38}$ For this reason, plays set at a royal court have a tendency to explore the well-known parallel between the family and the state, the cornerstone of patriarchalist thinking all over Europe. ${ }^{39}$ Given this political edge to female behavior in a courtly environment, Questiers's play is able to explore a broad range of cultural, political, and literary conventions for public femininity and individual women's responses to and negotiation of those conventions. Her main character has limited public influence, but in the end is forced to give up her personal wishes in favor of her public role. Along the way, she can withstand assaults on her virtue, and political order depends on her chastity and loyalty, but the play makes clear that this apparent agency comes at a cost: her private desires must be abandoned in favor of general order. Thus, her political prominence eventually requires the voiding of what we might construe as her inner or private self.

Questiers was a more prominent author than Verwers. A well-known poet, she wrote three versions of Spanish plays, all staged to some acclaim and most likely written in the full expectation that they would be performed. She came, unlike her predecessor, from a family with strong and clear theatrical connections. Her father, owner of a thriving plumbing business, had been a board member of one of the two main Chambers of Rhetoric and wrote plays for the Nederduytsche Academie (Dutch Academy), a theatrical institution that preceded the founding of the Schouwburg and that was intended to promote Dutch literary production partly by putting on plays in Dutch for the edification of the general population. Questiers herself was friends with some of the country's leading authors such as the famous playwright Joost van den Vondel, a fellow Catholic. Her connections with the Schouwburg, which also included its architect, her brother-in-law Philip Vingboons, may have helped get her plays performed on the stage. ${ }^{40}$ The three plays she wrote for the Schouwburg were moderately successful, and her third play, d'Ondanckbare Fulvius en

38 McKeon identifies a traditional approach to the relationship of public and private in absolutist representations of the two as parallel and continuous, even as people recognized them as distinct realms; the separation of the two into opposing spheres would gradually happen over the course of the seventeenth century. See McKeon, Secret History, xx. Plays that are fascinated with the court explore such traditional models of the relationship between public and private. See my Early Modern Women's Writing for an extensive discussion of these issues in writings by English and Dutch women.

39 See McKeon, Secret History, for the relationship between patriarchalism and the publicprivate relationship, especially Chapters 1 and 3 .

40 For the most up-to-date information on her biography, see Malou Nozeman, "Questiers, Catharina (1631-1669)," Digitaal vrouwenlexicon van Nederland, Huygens Instituut voor de Nederlandse Geschiedenis, web, 2014. Jautze, Álvarez Francés, and Blom classify her as a "peripheral poet," that is a playwright with connections to the Schouwburg (28). 
trouwe Octavia (The Ungrateful Fulvius and Faithful Octavia) was performed on the occasion of the reopening of the Schouwburg after its renovation in 1665 and therefore attended by large audiences. ${ }^{41}$ Her second play, Casimier, of gedempte hoogmoet (Casimir, or Pride Subdued, 1656) was one of the earliest stage productions to feature Nozeman and thus a public moment of artistic collaboration between women, predating the first performance of Verwers's play with women acting in leading roles. The Amsterdam city council attended the fourth performance of the play. ${ }^{42}$

For Casimier, Questiers selected what she thought was a play by Lope de Vega. Here too, our information on the source material is incomplete. We do know that the source for Casimier is Engañar para reynar (To Trick to Reign, 1649), a comedy written most likely by Antonio Enríquez Gómez, a Jewish converso playwright. ${ }^{43}$ Although it has been proven that Gómez did not live in Amsterdam at any time, it appears that his works circulated among the community of Sephardic Jews living in the city, which could give us insight into how Questiers may have acquired the play, perhaps in manuscript, and how she may have had it translated into prose Dutch. ${ }^{44}$ Unfortunately, her

41 The records listed on ONSTAGE show a mixed picture in terms of receipts for her plays, with the highest numbers for the performance of her third play and the lowest for Casimier.

42 Ben Albach mistakenly calls Questiers the first female playwright, but seems right in noting that it must have been a special occasion for the magistrates to witness the "play and performance by two female artists." See "Ariana Nooseman ontvangt $f$ f6,50 voor zeventien optredens in de Schouwburg: De eerste vrouw op het toneel van de Schouwburg," in Een theatergeschiedenis der Nederlanden: Tien eeuwen drama en theater in Nederland en Vlaanderen, ed. R. L. Erenstein et al. (Amsterdam: Amsterdam University Press, 1996), 234-41, 240. The first three performances got good audiences, perhaps for this reason, but the other four were not as well attended (see ONSTAGE).

43 It should be noted that the play was attributed to others in its own day, including Lope de Vega and Pedro Calderón de la Barca. Jaime Galbarro has helpfully provided me with information about Gómez in a private communication. He indicates that the play was most likely written originally in the 1630 , but cautions about overconfident attribution to Gómez. The main biographical source on Gómez is I. S. Révah's Antonio Enríquez Gómez: Un écrivain Marrane (v. 160o-1663), ed. Carsten L. Wilke (Paris: Chandeigne, 2003), which argues throughout against the long-standing misconception that Gómez lived and ended his life in Amsterdam.

44 Jautze, Álvarez Francés, and Blom provide further detail on prose translation from Spanish into Dutch, in particular on the intriguing translator Jacobus Baroces, who produced prose versions of Spanish plays for different playwrights for the Schouwburg $\left(3^{2-35}\right)$. They do not mention him in connection with Questiers, but given his Jewish background and connection with the Jewish community in Amsterdam, it is possible he was responsible for writing a prose version of this play. I have not been able to find a contemporary French translation that she could have used. 
dedicatory letter is vague on her source. She merely notes that she has adapted the text into a rhymed play, ensuring that the Spanish original has been, as she puts it, "reformed after the style of our Dutch Stage and Language."45

The play tells the story of Casimier, an illegitimate son who has usurped the Polish-Hungarian throne of his legitimate brother, Ladislaus. The latter has been missing since Casimier tried, unsuccessfully, to assassinate him. Everyone believes Ladislaus is dead, including his former beloved Clorinde (most likely played by Nozeman). She rebuffs many attempts by the evil title character at courting her, swearing she will remain faithful to his brother to keep a promise she has made to their father on his deathbed. By contrast with Pretiose, who is generally accompanied by Majombe, in Casimier, the female protagonist is tested in the absence of any protection, parental or male. Ladislaus himself is in hiding, living as a shepherd and secretly married to Irene, a young daughter of a nobleman he met in the woods. In order to regain the throne, Ladislaus decides to approach Clorinde covertly and pretend he still wants to marry her so she will help him displace his bastard brother. Irene, who has tried in vain to persuade her husband to stay in the woods with her, secretly follows him on his clandestine mission to the court to spy on her husband. Meanwhile, incensed by Clorinde's rejection, Casimier decides to rape and if necessary kill her in the middle of the night. Helped by Clorinde and an assortment of nobles, Ladislaus confronts his brother and overpowers him. Once crowned again, Ladislaus reveals the truth of his marriage to Irene in front of Clorinde, who understands the need for his deceit. In a final surprise move, Ladislaus gets Clorinde to marry Casimier, giving his brother and Clorinde the Hungarian half of the kingdom and ruling over the Polish half himself.

As is clear from this summary, Casimier is more political than Spaensche heydin in its concern with proper reign and exposure of tyranny as a consequence of both political and personal moral flaws, but it also includes pastoral scenes of a more romantic kind. Gómez's original play does not appear to have been written for public performance, considering its style and long speeches. ${ }^{46}$ Whether or not his play was performed, it is clear that Questiers felt she had to adjust the text to make it more suitable to the Amsterdam stage: she cut down

45 Catharina Questiers, Casimier, of gedempte hoogmoet. Bly-spel (Amsterdam: Smit, 1656), ar. She calls the play "naa de stijl van ons Neederduyts-Toneel en Taal hervormt."

46 Not much research has been done on this play. Glen F. Dille has not found any evidence of performance, though he does see the play as viable for stage production. But the length of some of the speeches suggests that it was possibly written in this form for a reading audience. "The Originality of Antonio Enríquez Gómez in Engañar para reinar," in Renaissance and Golden Age Essays in Honor of D. W. McPheeters, ed. Bruno M. Damiano (Potomac: Scripta Humanistica, 1986), 49-6o, esp. 50. 
some of the speeches, added minor figures and scenes, and wrote more detailed stage directions. Most conspicuously, unless she was using an unknown source, the first act is Questiers's own, making it problematic to designate her play as a translation as opposed to an adaptation - terms that appear in any case difficult to separate, given translation practices and the likelihood of intermediate prose translation at this time. ${ }^{47}$ Throughout the play, Questiers asks her audience to compare Clorinde and Irene and their perspective on the political arena of the court and to examine their status as women in a vexed position determined by their relationship to men in power. In presenting us with Clorinde and Irene, Questiers explores the complexity of the boundaries between the public and private spheres for courtly women.

Questiers's changes to Gómez's play reveal her interest in public femininity. Gómez opens with a pastoral scene in which Iberio (his Ladislaus) and Elena (Irene) express their love for each other during their first meeting, a situation which bears some resemblance to the meeting of Don Jan and Pretiose: in each case a male courtier falls in love with a young woman in a pastoral setting, testing his identity and allegiance to the court and its corrupt temptations. This association of Iberio with the court and Elana with the countryside replicates conventional gendered divisions between public and private, defined not merely in terms of visibility but also as public office and retirement; the traditional association of privacy with secrecy and lack of public office is thus confirmed. By contrast, Questiers upsets these gendered divisions by opening with a scene in which Clorinde discusses the political crisis with the nobles, followed by an unsuccessful attempt by Casimier to woo her in front of everyone. The coronation of Casimier is shown, a scene that opens the second act in Gómez, immediately followed by another confrontation between Casimier and Clorinde. These scenes, which precede the pastoral romance in Questiers, make the play more political from the outset but also, crucially, present Clorinde's public stature and virtuous steadfastness as central to the events that unfold.

Unlike her counterpart in Gómez, Clorinde quarrels with the nobles, who have allowed Casimier to displace his brother only for the sake of gaining

47 All versions I have consulted, including the 1649 printing and two manuscript versions available on digitally on the Biblioteca Digital Hispánica, have the same opening act. Citations from Gómez's play are taken from its earliest printing: Engañar para reynar, in Doze comedias las mas famosas que asta aora han salido de los meiores, y mas insignes poetas, vol. 3 (Lisbon, 1649), $\mathrm{Mr}-\mathrm{O}_{7} \mathrm{v} ; 151-196$. The manuscripts are attributed to Gómez in the $B D H$; the signatures are MS/17011 and MS/15080, the latter dated 1720 . A later printing of the play, dated 1762 , has the same opening, but the attribution is to Pedro Calderón de la Barca. 
peace after much suffering. In a stern moral tone, she deplores their weakness: "Alas! will it then come to pass / That in this fruitful land a Bastard shall rule! / Miserable Kingdom, what shame will come upon you." 48 With a strong voice that contrasts with the vacillating behavior of the men around her, she predicts that they will be punished, calls Casimier a tyrant, and swears that Ladislaus is still alive. Stanislaus reveals that Casimier loves her, but she immediately claims that she promised the brothers' father to marry and rule with Ladislaus and will not relent. In a short private scene with her lady-in-waiting Usebia (a character not in the original play), Clorinde expresses her undying love to Ladislaus in response to Usebia's advice to take Casimier's hand in marriage. When Usebia reminds her Casimier is Ladislaus's brother, she yet again denounces illicit sexuality and declares, "No bastard shall ever mix his blood with mine."49 Political and sexual illegitimacy are paralleled, and Clorinde's chaste constancy matches her political virtue, creating an exemplary female presence at the heart of the court, with what strikes us as a cohesive public and private presence.

This cohesiveness is enhanced by the variety of settings for Clorinde's confrontations with Casimier. First, we see her stand up to Casimier in a private conversation with him, asserting proudly that she has never been ruled by "staatssucht" (desire for power) and that she will not bow to his "minsught" (desire for love), calling herself as steadfast and unchangeable as a rock. ${ }^{50}$ The subsequent coronation scene repeats the argument between Casimier and Clorinde, this time in a public setting in front of the nobles. For Casimier, it is the first test of his power, and it ends in humiliation, followed by his degeneration into tyranny, which happens seemingly in response to these clashes with Clorinde. The varied settings and repeated conflicts imply that Clorinde's behavior, unlike that of the men at court, is virtuous no matter who is present. She moves seamlessly in and out of public and private spaces, willing to take Casimier on in front of other courtiers and reject him even when faced with him on her own. By Act Three, Casimier has isolated himself entirely: he denies all petitions from citizens, including one from Clorinde herself asking to be allowed to enter a monastery. He responds with a threat to burn the monastery and kill her. She is not fazed by his violence, functioning as an example and inspiration to some of the nobles, who finally conclude that Casimier must

48 "Helaes! zal't dan geschien / Dat in dit vruchtbaar land een Bastart zal gebieden! / Elendigh Koninghrijck, wat smaat zal u geschieden." Questiers, Casimier, Ar.

49 “Geen bastaart zal zijn bloet, oyt mengen onder't mijn”; ibid., A2r.

5o Ibid., A2v. 
be removed and killed. Her steadfastness, in other words, has real public and political impact.

More surprisingly, Clorinde's virtue contrasts not only with the behavior of men at court but also with the deceptive conduct of her beloved, the rightful King, which means that there is no male model of virtuous rule. While Clorinde impresses us with her honesty at court, Ladislaus is persuaded by Segismond, the stadholder of Poland, of the need to hide his marriage with Irene so that he can get Clorinde to help him return to the throne. In Gómez's play, the King is, as Glen Dille has argued, reprehensible and partly motivated to retreat into the woods by an inexplicable hatred of Isbela and a lack of responsibility. ${ }^{51}$ Questiers does not make him as culpable as Gómez. For instance, she changes the King by not showing his first meeting with Irene, which gives the impression that his primary motivation for retirement is romantic rather than unexplained hatred for Clorinde. Moreover, in both plays, the title has a double meaning, but Questiers's use of the title is less focused on the King. Gómez's title, To Trick to Reign, applies to Casimir, but also to Iberio, both of whom use trickery. In Casimier, the title is doubly relevant in a different way. The label of pride ("hoogmoet"), of which Casimier is generally accused, is used by Casimier himself to talk about Clorinde, and he is not the only one to apply the word to her. When Segismond counsels Ladislaus, he notes that they need Clorinde's support but first, "Her pride must be subdued, through cunning but not by force." 52 The play gives no indication that she might shift her allegiance so easily. Instead, the suspicion reflects badly on Ladislaus himself, who goes on to deceive Clorinde and Irene in order to regain the throne. Clorinde's plotting on his behalf, by contrast, is laudable, consisting in preparing the nobles for battle and hiding him in an emergency. Ladislaus's conviction that there is a need to subdue her pride, in other words, shows that political expediency affects him morally. But it also suggests the potential for seeing "pride" as a term that covers different forms of behavior that must, however virtuous its motivation, be controlled for the sake of public harmony.

Questiers uses the character of Irene to offer a reflection on women's place in the public realm of courtly politics, suggesting that her attitude to courtly femininity is fundamentally at odds with Verwers's. Unlike Clorinde, Irene is uncomfortable at court and leaves her secluded life in the woods only reluctantly. Her life in hiding with Ladislaus, in a space that is romanticized but also

$5^{1} \quad$ Dille, "The Originality," $5^{2 f f .}$

$5^{2}$ "Haar hoogmoet dient gedemt, door list maar met geen macht"; Questiers, Casimier, E2v. Although El Condestable calls her "altiva" or proud, this line does not occur in Gómez. Gómez, Engañar para reynar, N8v; 182. 
depicted realistically as populated with farmers like the comic Smolsky and his girlfriend Flora, shows that similar to Verwers's Pretiose, this young rural noblewoman is virtuous because she is anti-courtly. Rightly suspecting her husband, she decides to go to the court secretly to spy on her beloved Ladislaus and Clorinde. Once there, Irene must learn to conquer her jealousy in favor of his quest to regain the throne. At a crucial moment, when armed parties are gathering on both sides and Ladislaus is about to confront his brother, she suggests that they return to the woods together and leave the evil Casimier to rule: "seek rest with me / A cattle's pasture, that gives more pleasure / Than the Royal command. ${ }^{53}$ Although her pastoral sentiment is to some extent laudable, her mistaken desire to stay out of the public realm must be rejected as part of a learning process that will eventually qualify her for a position as queen. In this sense, she is, like Pretiose, eventually removed from the natural environment, but her anti-courtly attitude cannot persist. Her remarks also show that not all virtuous women fit readily into public roles, suggesting that Clorinde's natural ability to lead and speak openly at court sets her apart.

More explicitly than her source, Questiers's play explores the need for noble women to harmonize the conflict between personal feelings and public roles by subduing their own desires, particularly once they are married. We can also see Ladislaus's decision to marry Clorinde to his brother, her would-be rapist and murderer, in this light. Although Casimier promises to become a deserving husband, there is little in the play that indicates this is likely. The marriage is essentially concluded between the men as a political arrangement that will allow them both to rule, with Clorinde and Irene as their queens. Like Verwers, Questiers stages her conclusion about public femininity in three vertoningen. Female personifications of Justice, Peace, and Virtue manage to bind all parties to each other and reconcile the four individuals involved. Justice threatens Casimier, but is appeased by Peace; Virtue crowns Irene and provides unity to all by bringing down anger and desire for power and chasing hatred (possibly another personification) away. Clorinde's virtue and loyalty are mentioned first as the reason for Casimier's survival and second as the source of her reward, the crown. We learn that forgiveness is vital to the happy ending as the final lines read, "Thus must he, who can be rewarded by virtue, forgive evil, / Experience high old age, with peace here." ${ }^{54}$ The grammar is somewhat ambiguous, but the centrality of forgiveness and the rewards for loyalty suggest that the pride

53 She tells him, "zoeckt met my de rust, / Het weyde van het vee, dat geeft veel meerder lust. / Als't Konincklijck gebiet.” Questiers, Casimier, Grr.

54 "Zoo moet hy, die de deugt ken loone, 't quaat vergeeve, / Een hooge ouderdom, met vreede hier beleeven." Ibid., H2r. 
that has been subdued is not just Casimier's but also Clorinde's, in spite of the male pronoun used. The play leaves it a question if public femininity is capable of reforming the courtly arena: even though Casimier repents, the rightful king has deceived to gain power and restore order. Still, in spite of her apparent failure to change her political environment in a fundamental way, Clorinde represents a feminine ideal, remaining firm within her convictions for as long as she is able to, and Irene learns to emulate her example. That Clorinde consents to marry Casimier is a sign not only of her loyalty to the King but also of her willingness to forgo her own longings for the sake of public peace and her continued public presence, which will gain a new form once she is married.

Questiers is more interested in the conflict between public and private roles for women than Verwers, but she too conspicuously refuses to resolve all the problems her play brings up. Rather than denying the value of female courtliness in favor of an allegorical ideal, she addresses its complexity. This is possible because the public is not defined in terms of visibility and pleasing performance, but in terms of political influence. Ultimately, her leading women have to deny their private selfhood in favor of assigned political and public roles. While such a forced choice seems to indicate a loss of the romantic values espoused in Verwers's play, their ability to do so marks them as virtuous, and they end up performing a public service that is celebrated as an indication of a general change for the better.

We do not have records of actors for the season when Casimier was first performed, but it seems likely that Nozeman would have performed Clorinde, marking her theatrical appearance as a touchstone of public integrity. As Clorinde, she is threatened by disruptive male sexuality - exactly the kind of erotic response elicited by female publicity on stage - but she transforms it by suppressing her own desire for the sake of order and general peace. Thus, she fulfills a public function that is based on her role as royal female.

The engraved frontispiece in the printed edition of the play (Fig. 5.1) offers an interesting visual gloss on these issues. It is an unsigned image of the closing scene, set in the Amsterdam Schouwburg. It is a possibility that Questiers, who certainly signed other engravings, made it herself, though in the absence of a signature we can only speculate. It does, at the least, seem probable that she would have approved of the image as accompaniment to her play. The engraving shows what is perhaps an image of Nozeman herself as Clorinde, who is calmly standing by while the men fight, holding her hands in a position of prayer but with a slight smile that reveals her controlled demeanor. She is not in the center of the image like the three males or in the light like the men and the allegorical female figure in the background. Instead, she appears half in the shadows, drawing the viewer's eye to her reaction to the male spectacle in spite 


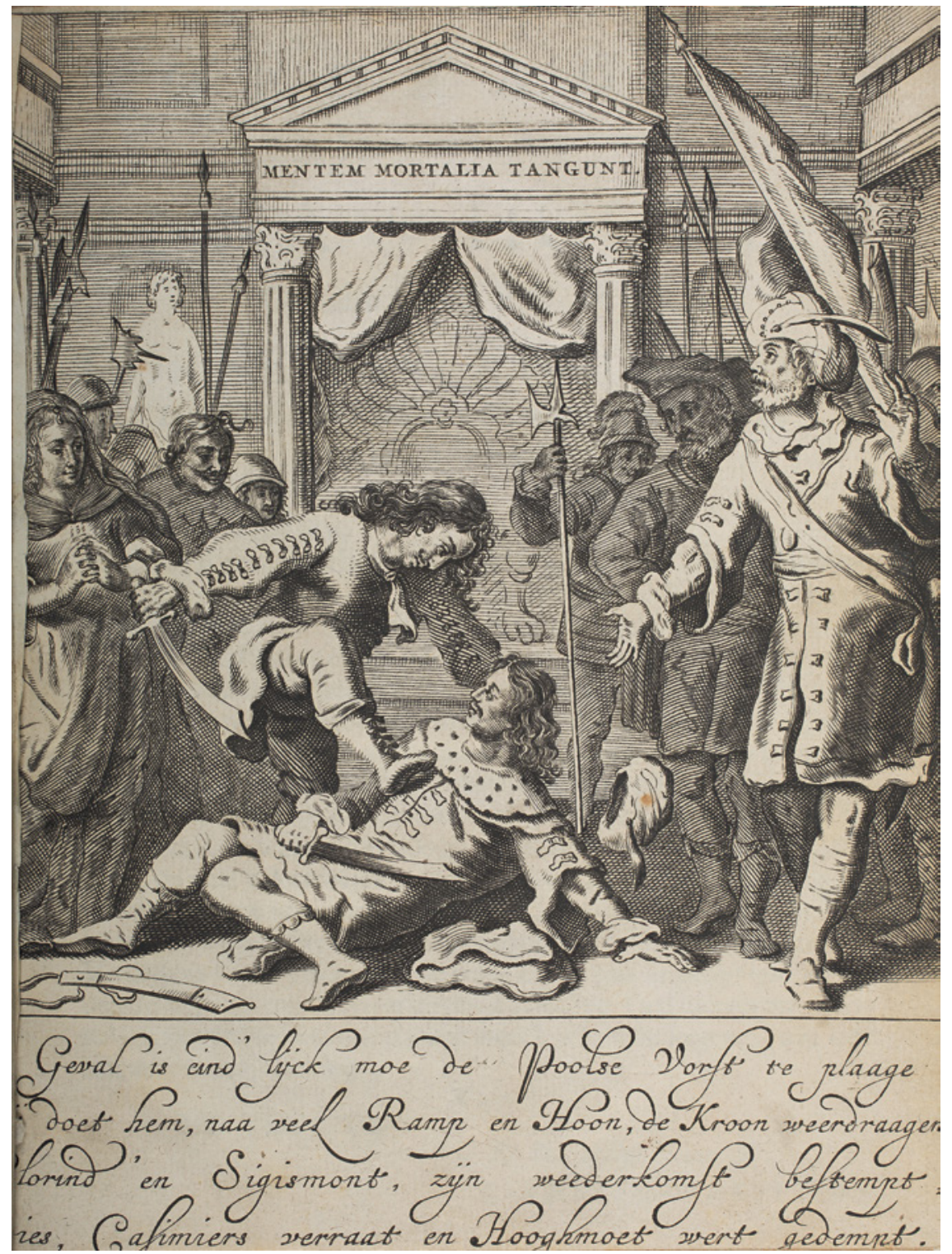

FIGURE 5.1 Anon., title page engraving for Catharina Questiers, Casimier of gedempte hoogmoet. Bly-spel (Amsterdam, 1656), Koninklijke Bibliotheek, The Hague

of her own modesty. This perfectly encapsulates women's double relationship to the male-dominated public realm in the play: Clorinde is important to resolving the conflict at the heart of the image, but marginalized visually at the same time, enabling her to contemplate the men from a position of moral superiority. 
The plays by Verwers and Questiers tell us that the earliest Dutch female dramatists wanted to represent publicly significant women to interrogate ideals of and ideas about public femininity. However virtuous the women in these plays may be, they do not achieve political agency because of it. Verwers reduces her female protagonist's reputation from what it is in her sources, even though she does represent her singing and dancing, which gives her a measure of public visibility, but Verwers stages these performances mainly in "private" settings. Pretiose's exemplarity is thus not primarily measured by her publicity but instead resides in her rejection of female courtliness, making her representative of the new Reformed ideals of womanhood. All the same, the play becomes ambivalent by the end, when Pretiose's fame is staged allegorically, so that she can be adored as passive presence, rather than as a conscious agent. This aligns her character with traditional absolutist imaginations of women as public paragons of virtue, whose influence is due to their nobility and physical presence, not to their actions and speech.

Questiers also offers a complex presentation of her leading ladies. Irene leaves the rural environment only reluctantly to assume a position at court, foregoing her anti-courtliness of necessity, whereas Clorinde, whose political influence and significance is considerable at first, must agree to a marriage that preserves peace but does not match her personal wishes or virtuous character. Clorinde is potentially a politically active and effective protagonist, but her agency must ultimately be contained by her environment, her "pride subdued." These ambivalent endings to the comedies should be read as contributions to the lively debates on the divisions between public and private and their impact on women in the Low Countries. What connects them is that in each case, women's voices disappear upon marriage; they are virtuous in withstanding unruly and even violent male sexual desire, but once paired up take up positions that deny them individuality outside of public perceptions. Thus, while Verwers and Questiers do not defy patriarchal restrictions imposed on women explicitly, we can see them exploring what Howell identifies as the contradictions inherent in patriarchy itself. While there are fundamentally conservative aspects to their plays and the genre in which they wrote, they put forward a possibility for reflection on public femininity as well as the complexity, variety, and inadequacy of male treatments of women. While these women playwrights could not yet imagine a coherent, powerful, and effective female presence, at court or outside it, they nonetheless allowed audiences to consider the intersections between femininity, public action, and sexuality, making playgoers question the conventions by which women were represented. 